University of Nebraska - Lincoln

DigitalCommons@University of Nebraska - Lincoln

Papers in the Earth and Atmospheric Sciences

Earth and Atmospheric Sciences, Department

\title{
Estimating hydraulic conductivity for the Martian subsurface based on drainage patterns - A case study in the Mare Tyrrhenum Quadrangle
}

Wei Luo

Northern Illinois University, wluo@niu.edu

Bartosz Grudzinski

Northern Illinois University

Darryll T. Pederson

University of Nebraska-Lincoln, dpederson2@unl.edu

Follow this and additional works at: https://digitalcommons.unl.edu/geosciencefacpub

Part of the Earth Sciences Commons

Luo, Wei; Grudzinski, Bartosz; and Pederson, Darryll T., "Estimating hydraulic conductivity for the Martian subsurface based on drainage patterns - A case study in the Mare Tyrrhenum Quadrangle" (2011). Papers in the Earth and Atmospheric Sciences. 266.

https://digitalcommons.unl.edu/geosciencefacpub/266

This Article is brought to you for free and open access by the Earth and Atmospheric Sciences, Department of at DigitalCommons@University of Nebraska - Lincoln. It has been accepted for inclusion in Papers in the Earth and Atmospheric Sciences by an authorized administrator of DigitalCommons@University of Nebraska - Lincoln. 


\title{
Estimating hydraulic conductivity for the Martian subsurface based on drainage patterns - A case study in the Mare Tyrrhenum Quadrangle
}

\author{
Wei Luo, ${ }^{1}$ Bartosz Grudzinski, ${ }^{1}$ and Darryll Pederson ${ }^{2}$ \\ 1. Department of Geography, Northern Illinois University, Dekalb, IL 60115, USA \\ 2. Department of Earth and Atmospheric Sciences, University of Nebraska-Lincoln, Lincoln, Nebraska 68588, USA \\ Corresponding author - W. Luo, tel 815 753-6828, fax 815 753-6872, email wluo@niu.edu \\ Present address of B. Grudzinski - Department of Geography, Kansas State University, Manhattan KS 66502, USA
}

\begin{abstract}
Hydraulic conductivity $K$, as the coefficient of proportionality in Darcy's Law, is critical in understanding the past Martian hydrologic cycle, climate, and landform evolution. However, $K$ and its spatial variability on Mars are thus far poorly constrained due to lack of accessibility. Using an innovative method based on surface drainage dissection patterns, which has been successfully tested in the Oregon Cascades on Earth, we estimated $K$ in the Mare Tyrrhenum Quadrangle on Mars. The basic assumption is that under long-term dynamic equilibrium conditions, the overall dissection pattern in a watershed as reflected in drainage density is controlled by the interplay among surface runoff, groundwater flow, topography, and aquifer properties. $K$ is calculated following a derivative of Darcy's Law under DuPuit-Forchheimer assumptions with drainage density $D$, valley depth $d$, recharge rate $R$, and aquifer thickness $H$ as inputs. The results are consistent with the published $K$ values and reveal spatial variability.
\end{abstract}

Keywords: hydraulic conductivity, drainage pattern, Mars, groundwater flow, dynamic equilibrium, DuPuit-Forchheimer assumptions

\section{Introduction}

Groundwater flow is governed by Darcy's Law, which states that the groundwater flow rate is proportional to the hydraulic gradient:

$$
q=-K_{d l}^{\frac{\pi}{d h}}
$$

where $q$ is the volumetric groundwater flow rate per unit area (or flux); $K$ is the hydraulic conductivity; and $d h / d l$ is the hydraulic gradient along the flow direction.

$K$ represents the resistance to groundwater flow within the porous medium and is determined by the intrinsic permeability $(k)$ of the medium, the fluid's dynamic viscosity $(\mu)$ and density $(\rho)$, and the acceleration of gravity $(g)$ (Deming, 2002):

$$
K=k \frac{\rho g}{\mu}
$$

Thus $K$ is a fundamental parameter in quantifying any groundwater flow system. On Earth, $K$ can vary by several orders of magnitude for the same type of rock (Freeze and Cherry, 1979). Its value is traditionally obtained by measuring discharge through a porous medium sample under different hydraulic gradients in the laboratory (Daniel, 1994), by conducting pumping tests in the field and observing the effect on water levels in the subsurface (Hornberger et al., 1998), or by computer modeling coupled with field measurements of quantities such as discharge and heat flow (e.g., Ingebritsen et al., 1992, 1994). On Mars, the groundwater flow systems have been recognized as being critical in understanding its past hydrologic and geologic history (e.g., Clifford, 1993; Hanna and Phillips, 2005; Luo and Howard, 2008; Harrison and Grimm, 2009) and there has been an on-going debate about the role of surface water vs. groundwater in forming the valley networks (e.g., Goldspiel and Squyres, 2000; Craddock and Howard, 2002; Hynek and Phillips, 2003; Lamb et al., 2008). However, $K$ on Mars is thus far poorly constrained due to inaccessibility to its subsurface. In previous studies $K$ has only been estimated based on terrestrial analogs or flow models, and often has been considered homogeneous throughout the study area (e.g., Carr, 1979; Zimbelman et al., 1992; Gulick, 1998; Harrison and Grimm, 2002; Hanna and Phillips, 2005), or at best with spatial variability theoretically simulated using a stochastic approach (Harrison and Grimm, 2009). In order to better understand the hydrology, climate, and landform evolution on Mars, $K$ and its spatial variability need to be better constrained using measurable data on Mars coupled with innovative methodologies. This study represents such an attempt by estimating $K$ and its spatial variability based on stream drainage dissection patterns derived from digital elevation model (DEM) data. Given the large variability of $K$, the purpose of this study is not to obtain the exact values but rather estimate the order of magnitude and reveal spatial variability, which has been successfully accomplished throughout the Cascade Range on Earth using the same methodology (Luo et al., 2010). 
The interaction between surface water and groundwater has been well documented in the literature (e.g., Freeze, 1987; Dunne, 1990). In general, regions with less permeable surface materials are commonly thought to be associated with higher drainage density $(D)$ because of higher surface runoff potential(DeVries, 1976). Although numerous studies have used empirical equations to correlate various drainage basin parameters in terms of surface runoff (e.g., Montgomery and Dietrich, 1989; Dietrich et al., 1993; Vogt et al., 2003; Jaeger et al., 2007), stream channels and drainage patterns also carry the imprint of groundwater flow systems as groundwater flow typically concentrates along joints and fractures (or other permeable features) where seepage weathering and sapping erosion are capable of weakening and removing material supporting the overburden (Craddock and Maxwell, 1993). These groundwater driven weathering and sapping processes lead to surface valley development and headward channel extension, which further concentrates groundwater flow at the points of incision due to higher and directional groundwater gradients, giving rise to and guiding further valley development (Pederson, 2001). Overland flow can play a significant erosive role, but the groundwater discharge and seepage induced weathering processes prepare and precondition the rocks for erosion preferentially in areas weakened by weathering. The resulting drainage system should reflect the distinct groundwater flow patterns. This linkage between valley development and the groundwater flow system develops a unique overall drainage pattern over geologic time that is controlled by the interplay between surface water, topography, and subsurface aquifer properties. The overall drainage pattern as expressed in $D$ can be derived from DEM data and forms the basis of our new methodology. This method has been tested in the Oregon Cascades on Earth and generated $K$ values matching the order of magnitude and spatial variability of those documented in the literature in various locations throughout the Oregon study area (Luo et al., 2010).

\section{Methodology}

The details of the methodology are described in Luo et al. (2010). Here we briefly summarize the key points as shown in Figure 1. The assumptions are that (1) a steady state dynamic equilibrium between discharge and recharge has been established through long-term interaction among surface water, groundwater, and topography such that the aquifer is effectively drained; and (2) groundwater flow is primarily horizontal and the hydraulic gradient is invariant with depth(i.e., Dupuit-Forchheimer assumptions apply). The length of effective groundwater drainage $W[L]$ is unique for specified hydrologic parameters: hydraulic conductivity $K\left[\mathrm{LT}^{-1}\right]$, recharge rate $R\left[\mathrm{LT}^{-1}\right]$, valley depth $d[\mathrm{~L}]$ and aquifer thickness $H[\mathrm{~L}]$ (see

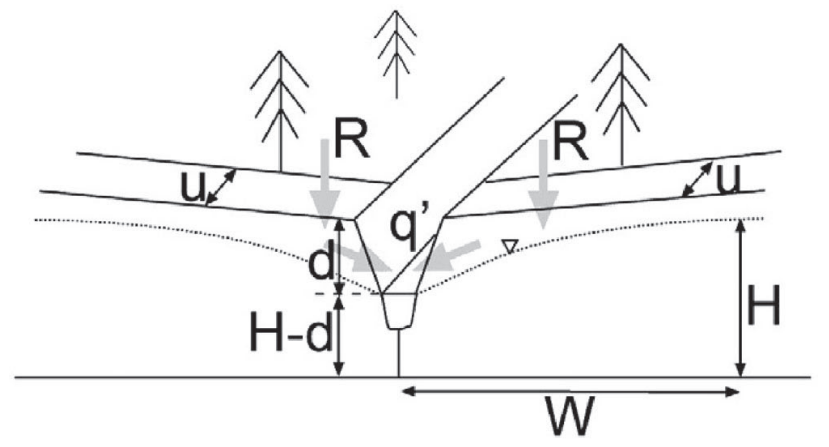

Figure 1. Diagram illustrating the conceptual model for deriving $K$ from drainage dissection patterns. See text for details. It is assumed that the valley shoulder elevation approximates the water table elevation at local groundwater divide. Modified from Luo et al., 2010.
Figure 1). If the aquifer is not effectively drained, more surface area away from the channel will be saturated, which will generate more runoff and groundwater recharge downslope. This will cause the river bank to become unstable and experience increased groundwater weathering and erosion. Bank instabilities and the positive feedback between surface topography and groundwater flow will promote more channel/tributary development until headward channel migration and/or the development of new tributaries has produced a drainage system with $D$ required to effectively drain the area of the aquifer discharging to the channel and a dynamic equilibrium between recharge and discharge is reached (Freeze, 1987; Craddock and Maxwell, 1993; Pederson, 2001; Luo et al., 2010). In such an effectively drained aquifer, the water table elevation at the groundwater divide is unlikely to reach the topographic surface. It is reasonable to assume that the valley shoulder elevation approximately represents the water table elevation at the groundwater divide. This elevation provides a value intermediate between the valley bottom and drainage divide elevations and variations in the $d$ value by a few factors will not appreciably change the results.

Under these assumptions, the discharge per unit length $(u=1)$ of the channel, $q^{\prime}\left[\mathrm{L}^{2} \mathrm{~T}^{-1}\right]$, is (Deming, 2002):

$$
q^{\prime}=\frac{1}{2} K\left(\frac{H^{2}-(H-d)^{2}}{W}\right) \text {. }
$$

This is fundamentally a 2-D equation assuming horizontal flow and can be derived from standard Darcy's Law. Under dynamic equilibrium conditions, $q^{\prime}$ can be estimated from recharge $R$ (which is the part of precipitation that infiltrates to recharge groundwater and equals annual precipitation $p$ multiplied by the infiltration percentage $i$; see Luo et al., 2010) as:

$$
q^{\prime}=R \times(2 W u) / u=2 R W
$$

The effective drainage length is related to $D$ as (Luo et al., 2010):

$$
W=\frac{1}{2 D}
$$

Rearranging Equation (3) to solve for $K$, and substituting Equations (4) and (5) yields:

$$
K=\frac{R}{D^{2}\left[H^{2}-(H-d)^{2}\right]} .
$$

Equation (6) is based on basic groundwater flow theory (Darcy's Law) and the assumptions described earlier. K can be estimated as long as the assumptions are justified and the parameters on the right side of Equation (6) can be reasonably estimated, which is discussed next.

\section{Study area}

The Mare Tyrrhenum Quadrangle (MC22) is an ideal Martian test site because the region had a significant amount of fluvial activity(Carr and Chuang, 1997; Luo and Stepinski, 2006), D has been estimated (Luo and Stepinski, 2006), and the geologic origin of surface material has been examined (Christensen et al., 2000). Luo and Stepinski (2006) mapped the valley networks in MC22 with a morphology-based algorithm and attributed their origin to a combination of runoff erosion and groundwater sapping with runoff playing a dominant role. Because many valley networks reach close to drainage divides (Irwin and Howard, 2002), the valley networks likely had developed over a period long enough to reach a mature stage. Although runoff had a substantial role in valley network development, groundwater (recharged by precipitation) was also important in draining un-dissected areas and maintaining fluvial discharges (Irwin and Howard, 2002). Geologic mapping and crater count dating show that the study area had undergone prolonged, ubiquitous, and intense fluvial erosion, which ceased abruptly during the late Noachian (Irwin and 


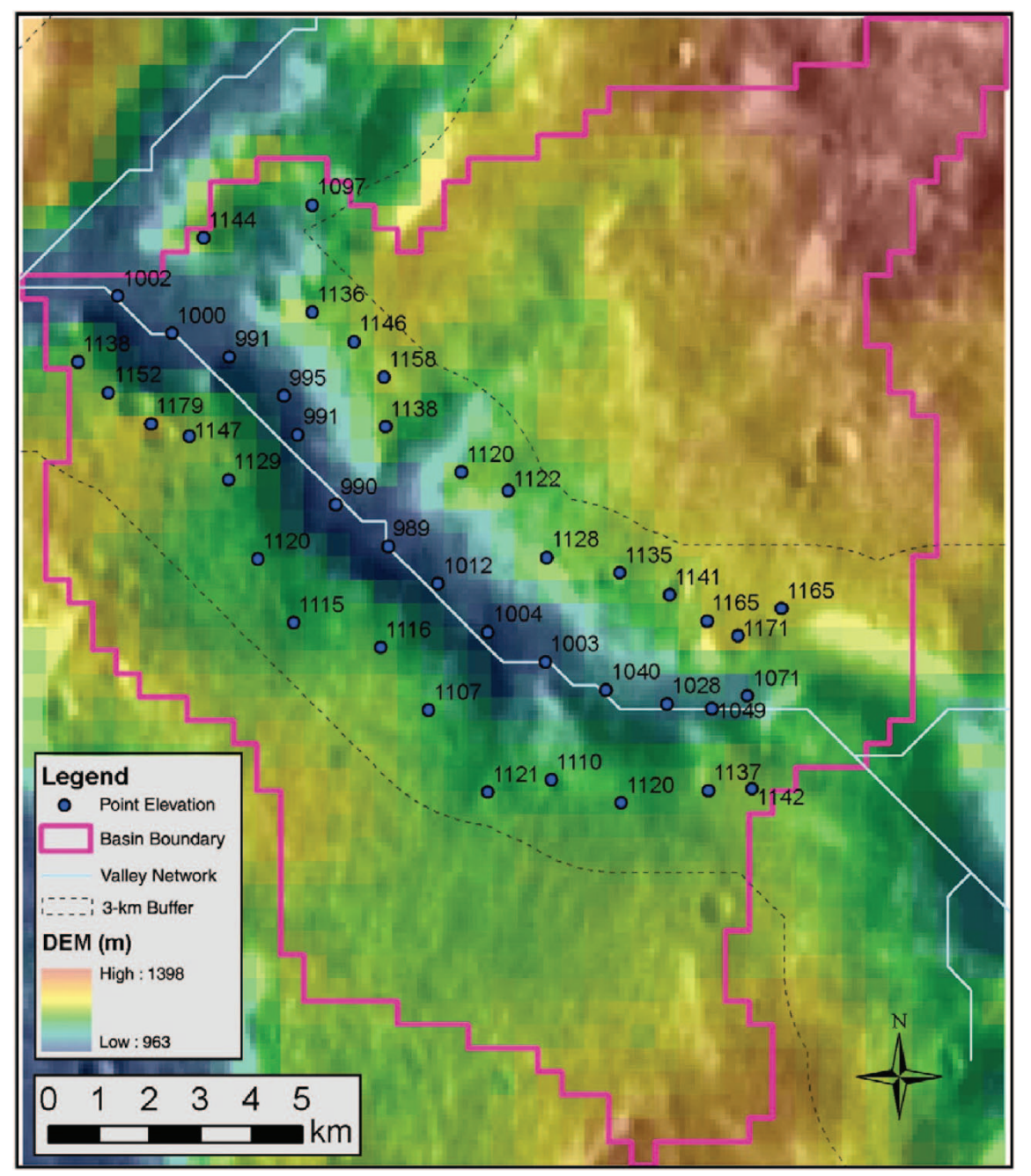

Figure 2. Close-up THEMIS day-time image of a watershed along part of Licus Vallis tinted with the MOLA DEM. The dots and associated numbers are elevations manually measured from the DEM. The differences between elevations of valley shoulders and valley bottom were averaged to produce a measured depth of $124.67 \mathrm{~m}$. The BTH with a radius of $\sim 3.25 \mathrm{~km}$ produced a depth average estimate for this watershed of $124.95 \mathrm{~m}$ and was determined as the optimum radius. The valley network is shown as a line for clarity. Also shown is the $3.25 \mathrm{~km}$ buffer around the valley network.

Howard, 2002). In addition, it is believed that valley network formation and degradation from flowing water on Mars had lasted for 400-600 million years (Craddock et al., 1997; Craddock and Howard, 2002). Thus it is reasonable to assume that during this prolonged, ubiquitous, and intense fluvial erosion period, a dynamic equilibrium was established such that the recharge from precipitation was equal to the discharge from groundwater and the groundwater system was effectively drained. Since this period ceased abruptly and post-Noachian modification has been minor, as evidenced in un-degraded small tributary valleys in high-resolution images (Irwin and Howard, 2002)and detailed morphometric analysis of valley networks (Williams and Phillips, 2001), the overall drainage pattern we observe today would not be significantly different from that formed during the intense fluvial erosion period. Therefore the valley networks observed today are capable of providing reliable estimates of $D$ and $d$.

\section{Parameter estimate}

In Equation (6), D was calculated using a method developed by Tucker et al. (2001) based on valley networks extracted using a morphology-based algorithm (Luo and Stepinski, 2006; Molloy and Stepinski, 2007) and averaged by watershed. The morphology-based algorithm was used because it extracts valleys that reflect spatial variation of dissection patterns and the algorithm eliminates the influence of large impact craters through a number of image processing techniques (Molloy and Stepinski, 2007). $d$ was estimated by subtracting the present day DEM (Smith et al., 2003) from a pre-incision surface constructed using the Black Top Hat (BTH) function (Rodriguez et al., 2002; Luo et al., 2010) and averaged by watershed. The BTH function involves a dilation operation followed by a closing operation. The dilation operation calculates the maximum elevation within a moving circle centered on a target cell in the original DEM. The closing operation calculates the minimum elevation within a moving circle centered on a target cell from the dilation result (Luo et al., 2010). Although the BTH function was applied to every cell, only the cells overlaying the valley network of a watershed were used to calculate the average as the valley depth estimate for that watershed. The radius of the circle should be sufficient to extend to the valley shoulder that is adjacent to the cell being targeted. The optimum radius of $\sim 3.25 \mathrm{~km}$ (or seven cells) was determined by comparing results from different radii with manually measured depths from the DEM at selected watersheds. An example is shown in Figure 2. The elevations of manually placed points were extracted from the DEM and differences between elevations of valley shoulders and valley bottom were averaged to produce the manually measured depth estimate of $123.8 \mathrm{~m}$. The BTH with the optimum radius produced a depth average estimate for this watershed of $124.9 \mathrm{~m}$, closely matching the manual estimate, and this optimum radius is used for the rest of the study area. We are aware that some cells in MOLA DEM (especially those near the equatorial area) are interpolated due to gaps between satellite ground tracks. However, since our approach is based on watershed scale average, the errors in elevation introduced 


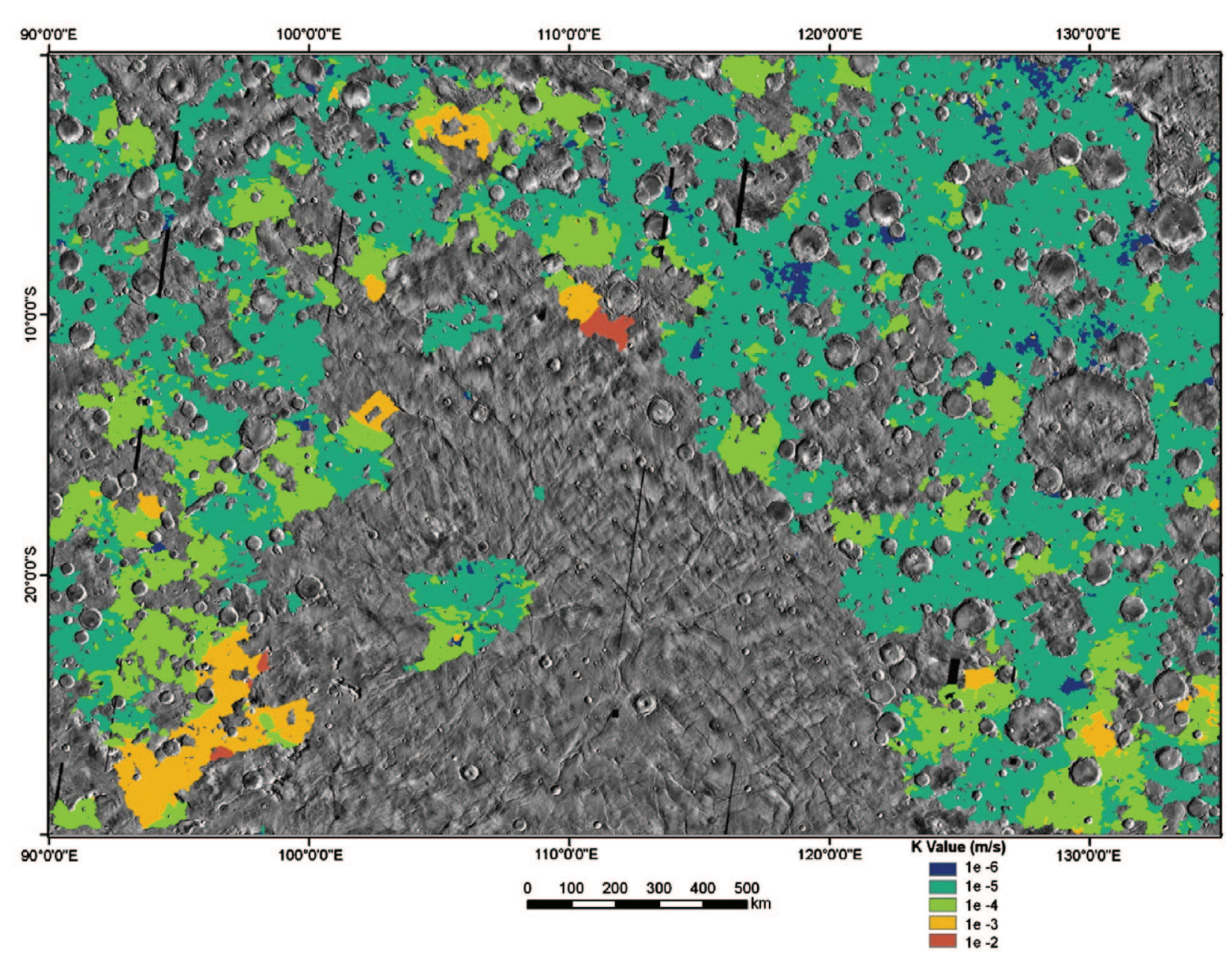

Figure 3. Map of $K$ by order of magnitude for the Mare Tyrrhenum Quadrangle with $R=0.02 \mathrm{~m} \mathrm{year}^{-1}$ and $H=100 \mathrm{~m}$. Areas not overlaid by the color gradient drain into closed depressions such as craters, or drain outside of the study area before flowing into a channel. For these areas $D$ could not be calculated (Luo and Stepinski, 2006) and thus $K$ cannot be defined. Note that $K$ is calculated by watershed, but watershed boundaries are not shown for clarity.

at some cells by interpolation would not make significant difference in the order of magnitude of the final $K$ estimate.

As there are no direct measurements of $R$ on Mars, we selected values from previous studies that estimated $R$ independent from assumed groundwater flow systems and these values are assumed to represent the average recharge rates over the evolution time scale of fluvial evolution of the valleys. Craddock and Maxwell (1993) examined crater degradation and valley network evolution in the Southern Highlands and estimated the rate of denudation to be 0.0001 to $0.005 \mathrm{~mm}$ year $^{-1}$, equivalent to denudation rates in terrestrial periglacial environments or in forested regions with annual precipitation of $\sim 0.2 \mathrm{~m}^{\text {year }}{ }^{-1}$ (e.g., Midwestern United States and southeastern Russia; Fournier, 1960). Irwin et al. (2005) estimated runoff production rates to be $0.3 \mathrm{~cm} \mathrm{day}^{-1}$ or $\sim 1 \mathrm{~m}$ year $^{-1}$ based on the morphology of a late-stage channel within Licus Vallis in the study area. The actual discharge from groundwater is likely smaller because the runoff production rate includes water discharged from both the surface and the subsurface (Irwin et al., 2005). In modeling the role of groundwater in forming valley networks on bedrock material, Luo and Howard (2008) used an $R$ value of 0.04 m year $^{-1}$, comparable to the $0.02 \mathrm{~m} \mathrm{year}^{-1}$ average $R$ into the Navajo Sandstone (Zhu, 2000; Heilweil et al., 2007). Considering the range and uncertainty, we used spatially uniform rates of $0.02,0.2$ and $2 \mathrm{~m} \mathrm{year}^{-1}$ in this study in order to span the orders of magnitude used in previous studies.
$H$ is also poorly constrained on Mars. Although the mean relief of watersheds (from the highest point to basin outlet), which is about $700 \mathrm{~m}$ for the study area, may provide an upper bound of $H$, we prefer to use the indirect estimates from previous research. Plaut et al. (2009) examined SHARAD radar data in Arcadia Planitia and found a widespread subsurface layer of 50 to $100 \mathrm{~m}$ thick, which may be made of volcanic material, aqueous sediments, or ground ice and was likely an active aquifer in the past. Previous studies of modeling groundwater flow systems on Mars have used $H$ values of 30

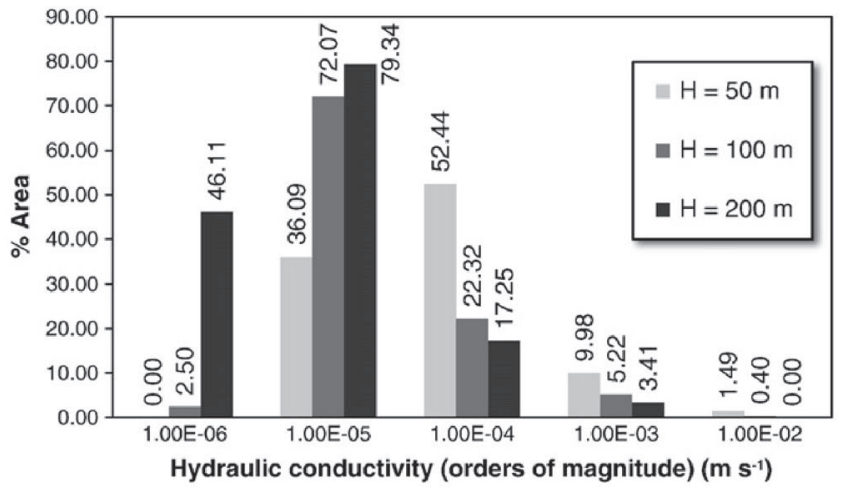

Figure 4. Histogram of estimated $K$ for $R=0.02 \mathrm{~m} \mathrm{year}^{-1}$ and different $H$ values. 
Table 1. Mean and standard deviation of calculated values of $K\left(\mathrm{~m} \mathrm{~s}^{-1}\right)$ for assumed values of $R$ and $H$.

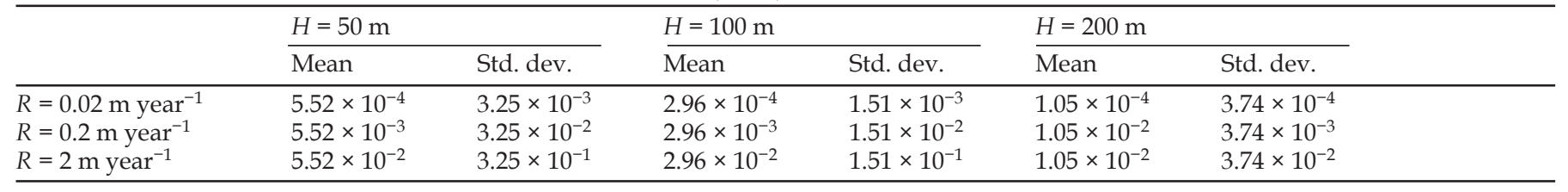

Table 2. Published estimates of $K\left(\mathrm{~m} \mathrm{~s}^{-1}\right)$ for Mars shallow aquifers.

\begin{tabular}{llll}
\hline Study area & Model & $K$ value $\left(\mathrm{ms}^{-1}\right)$ & Reference \\
\hline Circum-Chryse & Aquifer pressurization & $10^{-5}$ & Hanna and Phillips (2005) \\
Martian subsurface & Hydrothermal circulation & $10^{-7}-10^{-5}$ & Forsythe and Blackwelder (1998) \\
Northern Plains & Hydrosphere evolution & $10^{-3}$ & Carr (1979) \\
Mangala Valles & Outflow channel formation & $10^{-7}-10^{-2}$ & Zimbelman et al. (1992) \\
Martian subsurface & Groundwater outflow & $10^{-7}-10^{-3}$ & Gulick (1998) \\
\hline
\end{tabular}

Published permeability values were converted to K using dynamic viscosity of water at 273Kand gravity of Mars (see Equation (2)).

to $130 \mathrm{~m}$ (Parsons and Nimmo, 2009), 10 to $100 \mathrm{~m}$ (Perron et al., 2004), and100 to $200 \mathrm{~m}$ (Luo and Howard, 2008). To cover these ranges, we used the following spatially uniform $H$ values in this study: 50, 100, and $200 \mathrm{~m}$.

\section{Results and discussion}

Using Equation (6) and the above estimated parameters, $K$ is calculated at watershed level. The result for $R=0.02 \mathrm{~m} \mathrm{year}^{-1}$ and $H=100 \mathrm{~m}$ is shown in Figure $3 . K$ in the study area spans across five orders of magnitude $\left(10^{-6}\right.$ to $10^{-2} \mathrm{~ms}^{-1}$ ) and the spatial variability is clearly visible. The Terra Tyrrhenum region(western portion of map) has higher and a greater variability in $K$ than Terra Cimmeria (eastern portion of map), which may reflect differences in rock properties, a fracturing mechanism to open pore space, and/or different degrees of weathering that fill pore space. Applying other values of $H(50$ and $200 \mathrm{~m})$ resulted in the same overall spatial pattern of $K$ but different percentages of area in each order of magnitude (Figure 4). Using higher values of $R(0.2$ and $2 \mathrm{~m} \mathrm{year}^{-1}$ ) simply shifts the histogram (Figure 3 ) to the right by one order of magnitude. Table 1 shows the basic statistics of $K$ for all combinations of $H$ and $R$ values, which demonstrate that the $K$ value is more sensitive to changes in $R$ than in $H$. Our estimates of $K$ are generally consistent with previous studies(Table 2) and are primarily based on measurable DEM data. In addition, they reveal spatial variation of $K$ on Mars for the first time to the best of our knowledge.

Because the valley networks on Mars (and thus the drainage pattern as expressed in $D$ ) were developed under Martian gravity, $K$ calculated from Equation (6) reflects Martian gravity (i.e., it is $K_{\text {Mars }}$ ). To compare with terrestrial $K$ values, $K_{\text {Mars }}$ needs to be converted to its earth equivalent $K_{\text {Earth. }}$. Since ground water flow is essentially driven by gravitational energy (e.g., Freeze and Cherry, 1979) and since Earth's gravity is 2.66 that of Mars' gravity, all things being equal, the same hydraulic gradient on Earth would produce 2.66 the groundwater flow as compared with that on Mars. So $K_{\text {Earth }}=\left(g_{\text {Earth }} /\right.$ $\left.\mathrm{g}_{\text {Mars }}\right) K_{\text {Mars }}=2.66 K_{\text {Mars }}$. Similar scaling is also done in Forsythe and Blackwelder (1998). After conversion to Earth gravity, the terrestrial equivalent $K$ values still range between $10^{-6}$ and $10^{-2} \mathrm{~m} \mathrm{~s}^{-1}$ (with different percentage in each order as shown in Figure 4), which are within the range of $K$ for terrestrial basalt aquifers of $10^{-7}$ to $10^{-2} \mathrm{~ms}^{-1}$ (Hornberger et al., 1998). These results also match well with the results of Luo et al. (2010) for the High Cascades region in Oregon, ranging in order of magnitude from $10^{-5}$ to $10^{-3} \mathrm{~m} \mathrm{~s}^{-1}$. This is significant because the High Cascades subsurface is primarily composed of basalts
(Conrey et al., 2002). The only other rock type with this range of $K$ values is Karst limestone $\left(10^{-6}\right.$ to $\left.10^{-2} \mathrm{~m} \mathrm{~s}^{-1}\right)$, but extensive deposits of carbonates have not been detected on Mars (Bibring et al., 2006). The results of this study add supporting evidence that the subsurface of Mars is likely composed of basalt aquifers or impact-brecciated materials of similar porosity and permeability as has been assumed in previous studies (Carr, 1979; Gulick, 1998; Hanna and Phillips, 2005).

The assumptions of this method dictate that the method can only be used to estimate the near surface horizontal $K$ in areas where the interplay among surface drainage, groundwater, and topography has established a steady state dynamic equilibrium (Luo et al., 2010). However, $K$ at depth can be estimated using empirical exponential or logarithmic decay with depth (e.g., Manning and Ingebritsen, 1999; Clifford and Parker, 2001; Saar and Manga, 2004). The Dupuit-Forchheimer assumptions are reasonable because $83 \%$ of the cells on the sides of the valley networks have topographic slopes less than $10 \%$ (see Figure 5). The slope of $10 \%$ is the water table slope below which the error introduced by using the Dupuit-Forchheimer assumptions is considered negligible (Grismer and Rashmawi, 1993). The water table slopes for the cells near the valleys are generally expected to be smaller than topographic surface slopes as the groundwater table usually follows surface topography but in a subdued way and the postNoachian modification to surface topography is considered minor (Williams and Phillips, 2001; Irwin and Howard, 2002). In addition, the maximum $H$ value used $(200 \mathrm{~m})$ is much less than the average distance from the drainage divide to valley in the study area $(\sim 16 \mathrm{~km})$. The error introduced by assuming valley shoulder elevation as the water table elevation at the groundwater divide is unlikely to change the order of magnitude estimate in $K$.

Although drainage patterns may be controlled by many environmental factors, over long time scales ground water does play an important role in weakening and conditioning the bedrock material for these various environmental factors to work. The method used relies on the overall drainage patterns (not individual channels) that developed over geologic time. In addition to the justification already discussed in Section 3, Forsythe and Blackwelder's (1998) computer modeling of closed crater basins on Mars showed that the water table was most likely in geomorphic equilibrium with channels at the time of their development, because a transient condition would quickly lower the water table, preventing two adjacent channels to be formed, contrary to what is observed today. Many previous studies (e.g., Clifford and Parker, 2001; Luo and Howard, 2008) also invoked steady state groundwater 


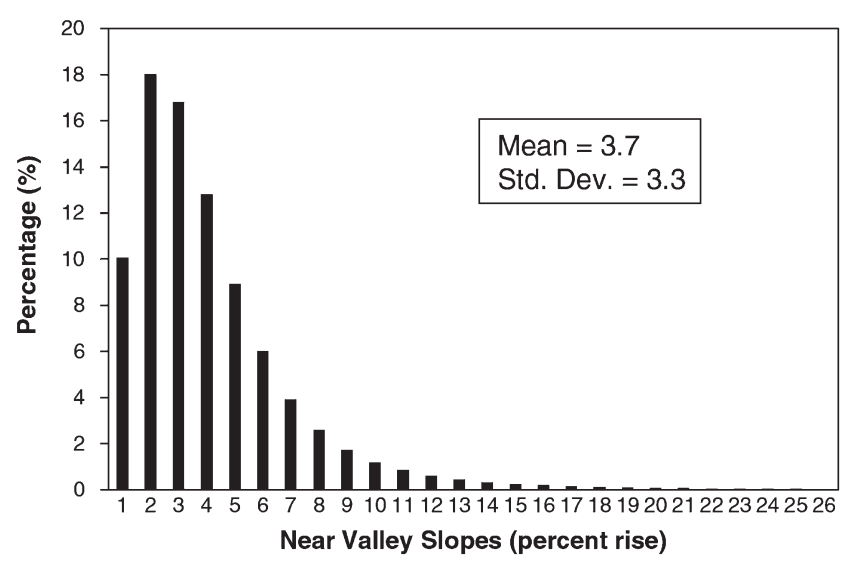

Figure 5. Histogram of topographic slopes near valleys (within 3-cell distance from either side of the valley cells; valley cells excluded).

flow in their models. Even if our study area had not had enough time to reach the dynamic equilibrium, i.e., the $D$ value used is smaller than what it should be under equilibrium condition, our method would still give an upper bound of $K$ and reveal a reasonable spatial variation pattern.

In summary, this study offers a new approach to estimate $K$ values on Mars and reveals its spatial variability by using actual DEM data and reasonable parameter estimates. Our method has a solid theoretical foundation in Darcy's Law for groundwater flow (Luo et al., 2010) and generated results that are reasonable and comparable with those documented in the literature. The uncertainties associated with some parameter estimates do not significantly change $K$ values (by more than one order of magnitude). Of the parameters in Equation (6), $d$ and $D$ are well constrained by DEM data; and $R$ and $H$ can be reasonably estimated using data from previous studies. Overall, the estimated $H$ ranges by a factor of four and the estimated $R$ range by three orders of magnitude. Changing $R$ by one order of magnitude changes $K$ by one order of magnitude; $K$ does not change by more than one order of magnitude using the three assumed values of $H$. More importantly, this method reveals spatial variability of $K$ based on actual DEM data, which has often been assumed homogeneous so far. Given that $K$ is known to have large variability, the results represent significant improvement over previous studies. This method can potentially be applied to other areas on Mars where the assumptions are met, as the DEM data is widely available.

Acknowledgments - We thank Goro Komatsu and an anonymous reviewer for Geomorphology for their helpful and constructive reviews, which greatly improved the quality of the paper. In particular, we would like to thank the anonymous reviewer who provided the informative comments on comparison of Earth and Mars $K$ values. This research is partially supported by NASA grant NNX08AM98G to Luo.

\section{References}

Bibring et al., $2006 \bullet$ J.-P. Bibring, Y. Langevin, J. F. Mustard, F. Poulet, R. Arvidson, A. Gendrin, B. Gondet, N. Mangold, and the OMEGA Team, Global mineralogical and aqueous Mars history derived from OMEGA/Mars Express data, Science 312 (2006), pp. 400-404.

Carr, $1979 \bullet$ M. H. Carr, Formation of Martian features by release of water from confined aquifers, Journal of Geophysical Research 84 (1979); doi: 10.1029/JB084iBO6p02995

Carr and Chuang, 1997 - M. H. Carr and F. C. Chuang, Martian drainage densities, Journal of Geophysical Research 102 (1997); doi: 10.1029/97JE00113
Christensen et al., 2000 • P. R. Christensen, J. L. Bandfield, M. D. Smith, V. E. Hamilton, and V. E. Clark, Identification of a basaltic component on the Martian surface from Thermal Emission Spectrometer data, Journal of Geophysical Research 105 (2000); doi: 10.1029/1999JE001127

Clifford, 1993 • S. M. Clifford, A model for the hydrologic and climatic behavior of water on Mars, Journal of Geophysical Research 98 (1993); doi: 10.1029/ 93JE00225

Clifford and Parker, 2001 • S. M. Clifford and T. J. Parker, The evolution of the Martian hydrosphere: implications for the fate of a primordial ocean and the current state of the Northern Plains, Icarus 154 (2001), pp. 40-79.

Conrey et al., 2002 • R. M. Conrey, E. M. Taylor, J. M. Donnely-Nolan, and D. R. Sherrod, North-central Oregon Cascades: Exploring petrologic and tectonic intimacy in a propagating intra-arc rift. In: G. W. Moore, Editor, Field Guide to Geologic Processes in Cascadia, Oregon Department of Geology and Mineral Industries Special Paper 36 (2002), pp. 47-90 Salem.

Craddock and Howard, 2002 - R. A. Craddock and A. D. Howard, The case of a warm, wet early Mars, Journal of Geophysical Research 107 (2002); doi: 10.1029/2001JE001505

Craddock and Maxwell, $1993 \bullet$ R. A. Craddock and T. A. Maxwell, Geomorphic evolution of Martian highlands through ancient fluvial process, Journal of Geophysical Research 98 (1993); doi: 10.1029/92JE02508

Craddock et al., $1997 \bullet$ R. A. Craddock, T. A. Maxwell, and A. D. Howard, Crater morphometry and modification in the Sinus Sabaeus and Margaritifer Sinus regions of Mars, Journal of Geophysical Research 102 (1997), pp. 13,321-13,340.

Daniel, $1994 \bullet$ D. Daniel, Hydraulic Conductivity and Waste Contaminant Transport Soil, American Society for Testing of Materials International, Philadelphia, PA (1994) 611 pp. .

Deming, 2002 - D. Deming, Introduction to Hydrogeology, McGrawHill, New York (2002) 480 pp. .

DeVries, 1976 • J. J. DeVries, The groundwater outcrop-erosion model; Evolution of the stream network in the Netherlands, Journal of Hydrology 29 (1976), pp. 43-50.

Dietrich et al., 1993 - W. E. Dietrich, C. J. Wilson, D. R. Montgomery, and J. McKean, Analysis of erosion thresholds, channel networks, and landscape morphology using a digital terrain model, Geology 101 (1993), pp. 259-278.

Dunne, 1990 - T. Dunne, Hydrology, mechanics, and geomorphic implications of erosion by subsurface flow. In: C. G. Higgins and D. R. Coates, editors, Groundwater Geomorphology: The Role of Subsurface Water in Earth-surface Processes and Landforms, Geological Society of America Special Paper 252 (1990), pp. 1-28.

Forsythe and Blackwelder, $1998 \bullet$ R. A. Forsythe and C. R. Blackwelder, Closed drainage crater basins of the Martian highlands: Constraints on the early Martian hydrologic cycle, Journal of Geophysical Research 103 (1998); doi: 10.1029/98JE01966

Fournier, 1960 - F. Fournier, Climat et Erosion: La Relation Entre l'Erosion du Sol par l'Eau et les Precipitations Atmospheriques, P.U.F, Paris (1960) 201 pp.

Freeze, $1987 \bullet$ R. A. Freeze, Modeling interrelationships between climate, hydrology, and hydrogeology and the development of slopes. In: M. G. Anderson and K. S. Richards, editors, Slope Stability, John Wiley \& Sons, New York (1987), pp. 381-403.

Freeze and Cherry, $1979 \bullet$ R. A. Freeze and J. A. Cherry, Groundwater, Prentice-Hall, Englewood Cliffs (1979) 604 pp.

Goldspiel and Squyres, $2000 \bullet$ J. M. Goldspiel and S. W. Squyres, Groundwater sapping and valley formation on Mars, Icarus 148 (2000), pp. 176-192.

Grismer and Rashmawi, 1993 - M. E. Grismer and E. A. Rashmawi, Dupuit-Forchheimer approximation may underestimate groundwater flow to San Joaquin River, California Agriculture 47 (1993), pp. 12-15.

Gulick, 1998 • V. C. Gulick, Magmatic intrusions and a hydrothermal origin for fluvial valleys on Mars, Journal of Geophysical Research 103 (1998); doi: 10.1029/98JE01321

Hanna and Phillips, $2005 \bullet$ J. C. Hanna and R. J. Phillips, Hydrological modeling of the Martian crust with application to the pressurization of aquifers, Journal of Geophysical Research 110 (2005), p. E01004; doi: 10.1029/2004JE002330 
Harrison and Grimm, 2002 • K. P. Harrison and R. E. Grimm, Controls on the Martian hydrothermal systems: Application to Martian valley network and magnetic anomaly formation, Journal of Geophysical Research E5 (2002); doi: 10.1029/2001JE001616

Harrison and Grimm, 2009 • K. P. Harrison and R. E. Grimm, Regionally compartmented groundwater flow on Mars, Journal of Geophysical Research E 4 (2009); doi: 10.1029/2008JE003300

Heilweil et al., 2007 • V. M. Heilweil, T. S. McKinney, M. D. Zhdanov, and D. E. Watt, Controls on the variability of net infiltration into desert sandstone, Water Resources Research 43 (2007), p. W07431; doi: 10.1029/2006WR005113

Hornberger et al., 1998 • G. Hornberger, J. Raffensperger, J. Wilberg, and K. Eshleman, Elements of Physical Hydrology, John Hopkins University Press, Baltimore (1998) 302 pp.

Hynek and Phillips, $2003 \bullet$ B. M. Hynek and R. J. Phillips, New data reveal mature, integrated drainage systems on Mars indicative of past precipitation, Geology 31 (2003), pp. 757-760.

Ingebritsen et al., $1992 \bullet$ S. E. Ingebritsen, D. E. Sherrod, and R. H. Mariner, Rates and patterns of groundwater flow in the Cascade Range volcanic arc, and the effects on subsurface temperatures, Journal of Geophysical Research 97 (1992), pp. 4599-4627.

Ingebritsen et al., $1994 \bullet$ S. E. Ingebritsen, R. H. Mariner, and D. R. Sherrod, Hydrothermal systems of the Cascade Range, North Central Oregon, U. S. Geological Survey Professional Paper (1994), p. 1044-L 86 pp.

Irwin and Howard, 2002 - R. P. Irwin III and A. D. Howard, Drainage basin evolution in Noachian Terra Cimmeria, Mars, Journal of Geophysical Research 107 (2002), p. E7; doi: 10.1029/2001JE001818

Irwin et al., 2005 • R. P. Irwin III, A. D. Howard, R. A. Craddock, and J. M. Moore, An intense terminal epochof widespread fluvial activity on early Mars: Increased runoff and paleolake development, Journal of Geophysical Research 110 (2005), p. E12; doi: 10.1029/2005/JE002460

Jaeger et al., $2007 \bullet$ K. L. Jaeger, D. R. Montgomery, and S. M. Bolton, Channel and perennial flow initiation in headwater streams: Management implications of variability in source-area size, Environmental Management 40 (2007), pp. 775-786.

Lamb et al., $2008 \bullet$ M. P. Lamb, W. E. Dietrich, S. M. Aciego, D. J. DePaolo, and M. Manga, Formation of Box Canyon, Idaho, by MegaFlood: Implications for seepage erosion on Earth and Mars, Science 320 (2008), pp. 1067-1070.

Luo and Howard, $2008 \bullet$ W. Luo and A. D. Howard, Computer simulation of the role of groundwater seepage in forming Martian valley networks, Journal of Geophysical Research 113 (2008); doi: 10.1029/2007JE002981

Luo and Stepinski, $2006 \bullet$ W. Luo and T. F. Stepinski, Topographically derived maps of valley networks and drainage density in the Mare Tyrrhenum quadrangle on Mars, Geophysical Research Letters 33 (2006), p. L18202; doi: 10.1029/2006GL027346

Luo et al., 2010 • W. Luo, B. P. Grudzinski, and D. Pederson, Estimating hydraulic conductivity from drainage patterns - A case study in the Oregon Cascades, Geology 38 (2010); doi: 10.1130/ G30816.1

Manning and Ingebritsen, $1999 \bullet$ C. E. Manning and S. E. Ingebritsen, Permeability of the continental crust: Implications of geothermal data and metamorphic systems, Reviews of Geophysics 37 (1999), pp. 127-150.
Molloy and Stepinski, $2007 \bullet$ I. Molloy and T. F. Stepinski, Automatic mapping of valley networks on Mars, Computers $\mathcal{E}$ Geosciences 33 (2007), pp. 728-738.

Montgomery and Dietrich, $1989 \bullet$ D. K. Montgomery and W. E. Dietrich, Source areas, drainage density, and channel initiation, Water Resources Research 25 (1989), pp. 1907-1918.

Parsons and Nimmo, $2009 \bullet$ R. A. Parsons and F. Nimmo, Fluvial discharge of Martian gullies: Slope measurements from stereo HiRISE images and numerical modeling of sediment transport, 40th Lunar and Planetary Science Conference, Abstract (2009), p. 1947.

Pederson, $2001 \bullet$ D. T. Pederson, Stream piracy revisited: A groundwater sapping solution, GSA Today 11 (9) (2001), pp. 4-10.

Perron et al., 2004 • J. T. Perron, M. Manga, and M. P. Lamb, Permeability, Recharge, and Runoff Generation on Mars, Workshop on Martian Valley Networks, Smithsonian Institution, Washington D. C. (2004).

Plaut et al., 2009 • J. J. Plaut, A. Safaeinili, B. A. Campbell, R. J. Phillips, N. E. Putzig, D. C. Nunes, and R. Seu, A Widespread Radar-Transparent Layer Detected by SHARAD in Arcadia Planitia, Mars, 40th Lunar and Planetary Science Conference, March 23-27, 2009 (2009).

Rodriguez et al., 2002 • F. Rodriguez, E. M. Pierre, P. CourjaultRade, and J. Darrozes, The black top hat function applied to a DEM: A tool to estimate recent incision in a mountainous watershed (Estibere Watershed, Central Pyrenees), Geophysical Research Letters 29 (2002); doi: 10.1029/2001GL014412

Saar and Manga, 2004 • M. O. Saar and M. Manga, Depth dependence of permeability in the Oregon Cascades inferred from hydrogeologic, thermal, seismic, and magmatic modeling constraints, Journal of Geophysical Research 109 (2004), p. B04204; doi: 10.1029/2003JB002855

Smith et al., 2003 • D. Smith, G. Neumann, R. E. Arvidson, E. A. Guinness, and S. Slavney, Mars Global Surveyor Laser Altimeter Mission Experiment Gridded Data Record, MGS-M-MOLA5-MEGDR-L3-V1. 0, NASA Planetary Data System, St. Louis, Mo (2003).

Tucker et al., 2001 • G. E. Tucker, F. Catani, A. Rinaldo, and R. L. Bras, Statistical analysis of drainage density from digital terrain data, Geomorphology 36 (2001), pp. 187-202.

Vogt et al., $2003 \bullet$ J. V. Vogt, R. Colombo, and F. Bertolo, Deriving drainage networks and catchment boundaries: a new methodology combining digital elevation data and environmental characteristics, Geomorphology 53 (2003), pp. 281-298.

Williams and Phillips, $2001 \bullet$ R. Williams and R. Phillips, Morphometric measurements of Martian valley networks from Mars Orbiter Laser Altimeter (MOLA) data, Journal of Geophysical Research 106 (2001); doi: 10.1029/2000JE001409

Zhu, $2000 \bullet$ C. Zhu, Estimate of recharge from radiocarbon dating of groundwater and numerical flow and transport modeling, Water Resource Research 9 (2000); doi: 10.1029/2000WR900172

Zimbelman et al., 1992 • J. R. Zimbelman, R. A. Craddock, R. Greeley, and R. O. Kuzmin, Volatile history of Mangala Valles, Mars, Journal of Geophysical Research 97 (1992), pp. 18,309-18,317. 